\title{
Imam Shamsi Ali dan Upaya Rekonstruksi Citra Islam dan Indonesia di Amerika Serikat
}

\author{
Minhajuddin ${ }^{1, *}$ \\ ${ }^{1}$ Fakultas Falsafah dan Peradaban; Universitas Paramadina; Jl. Gatot Subroto No.Kav. 97 RT \\ 4/ RW 4, Mampang Prpt, Kec Mampang Prpt, Jakarta Selatan (12790), 02179181188; email: \\ minhajuddin@students.paramadina.ac.id \\ * Korespondensi: e-mail: minhajuddin@students.paramadina.ac.id
}

Submitted: 19/04/2021; Revised: 03/09/2021; Accepted: 08/09/2021; Published: 30/09/2021

\begin{abstract}
This Paper Aims to examine a figure of Imam Shamsi Ali who comes from Bulukumba, South Sulawesi. He is being an outstanding Da'i in New York in promoting Islam by his identity as a Muslim and Indonesian. This writing using qualitative approach and the data from relevant literature studies such as books, journals, thesis, and websites. This research shows that Imam Shamsi Ali getting his successful in Promoting the Image of Islam and Indonesia rely on the way He identify Islam by Tolerance in form of interfaith dialogue regardless of ethnicity, religion, race and groups, and remains keeping his identity as a Muslims as well as Indonesians. throughout His integrity brings a significant change of Islam and Indonesia in United state particularly in New York.
\end{abstract}

Keywords: Imam Shamsi Ali, Tolerance, Islam, Indonesia, United State

\begin{abstract}
Abstrak
Tulisan ini mencoba menganalisa sepak terjang seorang Imam Shamsi Ali sebagai individu yang berasal dari salah satu kota kecil Bulukumba, Sulawesi Selatan, yang kemudian menjadi Da'i di New York dengan mengedepankan identitasnya sebagai seorang Muslim sekaligus sebagai orang Indonesia yang mampu mengubah citra Islam dan Indonesia dalam pandangan masyarakat Amerika Serikat yang sudah terlanjur phobia. Penulis menggunakan metodologi penelitian kualitatif dan data yang digunakan berasal dari studi literatur yang relevan seperti buku, jurnal, karya tulis skripsi dan tesis serta website berita yang dapat dipertanggungjawabkan kebenaran datanya. Penelitian ini menunjukkan bahwa keberhasilan Imam Shamsi Ali dalam merekonstruksi citra Islam dan Indonesia terletak pada keteguhannya mengedepankan toleransi dalam wujud dialog antar agama (interfaith dialogue) tanpa memandang suku, agama, ras dan antar golongan (SARA), namun tetap tidak meninggalkan Identitasnya baik sebagai seorang Muslim maupun sebagai orang Indonesia. Integritas yang dimiliki oleh Imam Shamsi Ali membawa perubahan yang signifikan bagi citra Islam dan Indonesia di Amerika Serikat khususnya di New York.
\end{abstract}

Kata Kunci: Imam Shamsi Ali, Toleransi, Islam; Indonesia, Amerika Serikat

\section{Pendahuluan}

Pasca serangan 9/11 yang menghancurkan menara kembar World Trade Center (WTC), hubungan antara negara barat yang direpresentasikan oleh Amerika Serikat dengan negara-negara Muslim yang diidentikkan dengan negara di kawasan Timur Tengah, semakin memanas. Pasca serangan 9/11, mantan presiden Amerika Serikat yang menjabat saat itu, George W Bush menyampaikan pesan melalui pidato yang sangat terkenal dan mengubah 
tatanan perpolitikan Internasional. "either you are with us, or you are with the terrorist." sebuah pernyataan yang sarat akan makna bahwa semua negara hanya memiliki dua pilihan, ikut dengan Amerika Serikat dalam proyek the Global War of terrorism dan jika tidak memilih berarti menjadi musuh Amerika Serikat. Momen tersebut serta merta mengubah tatanan Politik luar negeri di seluruh dunia yang sebelumnya tidak menjadikan isu Teroris sebagai sebuah hal yang penting, kemudian akhirnya menyetujui gagasan Amerika Serikat dan memasukkan isu Terorisme sebagai poin penting dalam perumusan Politik luar negeri. Tidak mengherankan jika tahun-tahun setelah kejadian itu, mayoritas negara di dunia menyatakan perang terhadap terorisme yang secara implisit ditujukan kepada Islam dan organisasi Al-Qaeda dijadikan sebagai simbolisasi gembong Teroris dengan pimpinan tertinggi Osama bin Laden.

Peristiwa 9/11 menjadi puncak meningkatnya citra negatif terhadap Islam atau istilah populernya Islamophobia di negara Barat khususnya di Amerika Serikat. Berbagai macam tindakan intimidasi dilakukan oleh masyarakat Amerika Serikat terhadap warga Muslim dalam berbagai bentuk baik secara verbal maupun kekerasan fisik. Kekerasan verbal seringkali berupa makian di tempat umum, cacian yang ditujukan terhadap seseorang yang menggunakan identitas Islam seperti perempuan berjilbab dan laki-laki yang berjenggot dan menggunakan jubah sedangkan dalam bentuk fisik seperti pengrusakan toko warga Arab, penusukan, penembakan dan berbagai tindakan fisik lainnya yang memakan korban jiwa serta penyerangan Masjid. Islamophobia di Amerika Serikat bersifat berlangsung secara struktural, sistemik dan terinstitusionalisasi bahkan diekspresikan melalui budaya, politik dan kebijakan (Love, 2017).

Momen tersebut juga menjadi pertarungan sesungguhnya antara Peradaban Barat dengan Peradaban Islam seperti yang dipaparkan dalam buku Samuel Huntington, meskipun pada realitasnya, dunia Islam yang dirugikan dalam berbagai hal. Sejatinya bahwa perang Peradaban tidak akan pernah seimbang jika salah satu pihak menguasai lebih banyak instrumen dan media menjadi salah satu instrumen terbaik dalam perang wacana, Amerika Serikat mempunyai semua instrumen tersebut. Sebuah pertarungan yang tentu saja secara kalkulatif akan dimenangkan oleh pihak Barat namun kenyataannya sampai saat ini, Amerika Serikat tidak benar-benar mendominasi dunia Islam bahkan sebaliknya, Islam tumbuh subur di Amerika Serikat mewarnai peradaban Amerika Serikat yang sangat heterogen.

Pada saat kejadian 9/11, seorang Imam di Islamic Cultural Center (ICC) New York yang berasal dari Indonesia, sedang dalam kereta nomor 7 dalam perjalanan bekerja di misi Indonesia untuk PBB. Sang Imam belum memahami apa yang sebenarnya terjadi sebelum sampai di rumahnya (Schneier \& Ali, 2014). Imam Shamsi Ali adalah seorang Da'i yang berasal dari kota kecil di Bulukumba, Sulawesi Selatan. Dikenal dengan panggilan Utteng sejak kecil, Imam Shamsi Ali hidup layaknya anak desa pada umumnya. Dikenal sebagai anak pemalas dan nakal pada masa di sekolah dasar, Imam Shamsi Ali kemudian meniti perjalanan akademisnya ketika diikutkan di Pesantren. Setelah tamat di Pesantren, Imam Shamsi Ali kemudian melanjutkan pendidikannya di Pakistan (Nava, 2013). Perjalanan dakwahnya berlanjut ke Jeddah kemudian berlabuh di New York. 
Pasca peristiwa 9/11 meledak, tugas Imam Shamsi Ali menjadi sangat berat karena stigma mayoritas masyarakat Amerika Serikat seketika menjadi Islamophobia dan menganggap bahwa Islam adalah agama teroris. Sebuah perubahan drastis yang harus dijalani sejak Imam Shamsi Ali tinggal di New York. Kehidupan toleransi di Amerika Serikat seakan menjelma menjadi tidak ramah bagi umat Islam dan seketika lirik bait pada lagu kebangsaan Amerika Serikat "the land of the free and the home of the brave" tidak berlaku lagi bagi mereka yang menggunakan identitas Islam. Bahkan post-9/11, retorika Islamophobia menjadi jualan politik dalam semua level politik di Amerika Serikat (Love, 2017).

Imam Shamsi Ali tidak hanya menjadi korban dari satu identitas sebagai seorang Muslim karena di lain sisi, juga seorang yang berasal dari Indonesia yang notabene adalah negara dengan populasi Muslim terbesar di dunia sehingga dua identitas tersebut menyatu dalam dirinya yang kemudian menjadikan beban yang tidak mudah untuk dijalani di tengah situasi yang tidak mendukung, meskipun identitas fisik sebagai seorang Muslim tidak dimiliki oleh Imam Shamsi Ali seperti memelihara jenggot dan memakai Jubah namun namanya sangat identik dengan Islam. Rentetan bom bunuh diri di Indonesia pasca serangan 9/11 pun semakin menambah beban psikologis Imam Shamsi Ali yang hidup dengan Identitas Islam dan Indonesia di Amerika Serikat sebagai pusat Islamophobia berkembang pesat.

Imam Shamsi Ali tidak kalah atas keadaan bahkan sebaliknya, Imam Shamsi Ali menempuh langkah nyata dalam menjawab keadaan bahwa stigma mayoritas masyarakat Amerika Serikat terhadap Islam pada umumnya dan Indonesia khususnya sebenarnya keliru dan serangan Teroris yang didalangi oleh kelompok yang mengatasnamakan Islam, sebenarnya sama sekali tidak merepresentasikan identitas Islam secara utuh. Perjalanan dalam mengembalikan citra Islam yang sesungguhnya tidak mudah dan mengalami begitu banyak hambatan.

Perjalanan dakwah di bumi Amerika Serikat tidak semulus dengan dakwah yang dilakukan di negara-negara dengan penduduk yang mayoritas Muslim. Kehadiran Imam Shamsi Ali di Amerika Serikat sangat tepat untuk menjadi kepingan kecil rekonsiliasi dunia Barat dengan dunia Islam dengan membawa dua Identitas di dalam dirinya yaitu Islam sebagai agamanya dan Indonesia sebagai asalnya yang merupakan negara dengan populasi Muslim terbesar di dunia. Jalan dakwah yang ditempuh secara inklusif dan toleran menjadi angin segar bagi perbaikan hubungan dunia barat dengan dunia Islam ketika di saat yang sama, masyarakat barat memandang Islam sebagai sebuah agama yang penuh dengan kekerasan karena mereka mendapatkan potret Islam dari media yang terus menerus memproduksi berita mengenai konflik yang terjadi di Timur tengah. Langkah selanjutnya yang dilakukan oleh Imam Shamsi Ali adalah menerapkan Islam yang rahmatan lil alamin dengan mengedepankan dialog untuk mencari solusi tidak hanya dengan umat Muslim namun juga dengan umat agama lain. 


\section{Metode Penelitian}

Dalam sebuah penelitian yang baik, sangat penting untuk menentukan level analisis untuk memudahkan para pembaca dalam memahami dari sudut mana penulis menyajikan argumen-argumen yang disajikan dalam tulisan. Sejatinya bahwa dalam satu tema tulisan, bisa dielaborasi dari berbagai level analisis sehingga menghasilkan kesimpulan yang berbeda. Menurut Mochtar Mas'oed bahwa terdapat 5 level analisa antara lain Individu, kelompok individu, negara bangsa, multi-negara dan sistem internasional (Mas'oed, 1994). Dalam tulisan ini akan menekankan pada level analisis individu yang direpresentasikan oleh Imam Shamsi Ali. Unit eksplanasi dalam tulisan ini adalah fenomena Islamophobia yang meningkat pasca peristiwa 9/11.

Tulisan ini menggunakan Teknik kualitatif yang populer digunakan dalam penelitian hubungan internasional. Penelitian kualitatif didefinisikan sebagai Teknik penelitian yang intuitif dan sistematis untuk membantu peneliti menghasilkan pengetahuan dengan fokus penelitian pada makna (meanings) dan pemahaman (understanding) daripada kuantifikasi (Bakry, 2016).

Dalam studi ilmu hubungan Internasional, konsep identitas mendapat perhatian yang cukup signifikan setelah berkembangnya perspektif Konstruktivisme pasca berakhirnya perang dingin. Teori ini menjadi antitesa dari dua aliran teori besar dalam hubungan internasional yaitu Realisme dan Liberalisme. Konstruktivisme adalah teori dalam hubungan internasional yang meyakini bahwa segala tindakan dalam dunia internasional adalah hasil dari konstruksi sosial bukan hanya sekedar kepentingan nasional. Dalam kajian ilmu hubungan internasional, perspektif Liberalisme menganggap bahwa sistem anarki menempatkan negara-negara dalam potensi kerjasama antar negara, Realisme menyatakan sistem anarki memberi peluang bagi negara untuk berperang sedangkan Konstruktivisme sendiri yang menganggap bahwa anarchy is what state makes of it (Wendt, 1992).

Identitas pada umumnya merupakan atribut atau penanda yang terdapat pada diri seseorang atau aktor yang kemudian mendorong mereka dalam bertindak (Wendt, 1994). Identitas juga dimaknai sebagai sebuah perasaan memiliki yang timbul dalam diri seseorang karena persamaan latar belakang dan kepentingan yang sama (Dixon, 2011). Negara bangsa yang kemudian melahirkan perasaan nasionalisme dalam diri masing-masing masyarakatnya adalah bentuk identitas yang lahir dari persamaan latar belakang dan kepentingan yang sama dan seringkali vis a vis dengan identitas masyarakat yang berasal dari negara yang berbeda. $\mathrm{Di}$ lain sisi, Francis Fukuyama menjelaskan bahwa seringkali identitas tersebut dihubungkan dengan ras, etnisitas dan agama (Fukuyama, 2018).

Jika berbicara mengenai identitas Islam maka tidak bisa dilepaskan dari identitasidentitas indrawi yang berkoneksi dengan budaya misalnya Jilbab, Burkak, memelihara jenggot, memakai celana yang menghindari isbal dan budaya lainnya yang terlihat secara indrawi, meskipun hal-hal tersebut di sebagian golongan dalam Islam merupakan sebuah kewajiban. Identitas dalam Islam juga bisa berupa kewajiban rutinitas misalnya shalat, puasa di bulan Ramadan, sedekah, dan perintah agama lainnya yang merupakan kekhasan dalam agama 
Islam yang tidak dilakukan oleh identitas agama selain Islam dan Identitas semacam ini yang harus diperkuat oleh umat Muslim tanpa menyampingkan Identitas yang bersifat kebudayaan.

Dalam ranah ke-Indonesiaan, identitas lebih banyak bersentuhan dengan hal yang berkaitan dengan budaya, misalnya yang paling sering diperkenalkan sebagai Identitas Indonesia adalah Batik, acara-acara Kebudayaan seperti pertunjukan Budaya seperti tari-tarian daerah, makanan khas dan kebudayaan lain namun ada juga Identitas keindonesiaan yang sifatnya value misalnya gotong royong, ramah kepada semua orang, suka membantu dan sebagainya. Jika dikaitkan dengan konsepsi Identitas menurut Wendt maka Identitas keindonesiaan masuk dalam kategori Identitas pertama yang terbentuk secara alamiah.

Dengan menggunakan analisa Identitas yang dikemukakan oleh Wendt, maka Identitas yang melekat dalam diri Imam Shamsi Ali bisa dikategorikan dalam dua jenis Identitas yaitu Identitas pertama yang muncul secara alamiah yang dibawa sejak lahir. Imam Shamsi Ali lahir sebagai seorang Muslim dan lahir di Indonesia otomatis kedua Identitas tersebut melekat dalam dirinya kemudian Identitas kedua yang dipengaruhi oleh ideologi Agama dimana Imam Shamsi Ali yang tumbuh dalam suasana Pesantren dan belajar Islam di Pakistan dan Arab Saudi maka serta merta nilai Islam terinternalisasi dalam dirinya.

Konsep toleransi menjadi perdebatan panjang antar sesama pemeluk agama. Sebuah konsep yang mungkin sampai sekarang belum disepakati dalam pengertian dan batasanbatasannya sehingga diartikan berbeda misalnya dalam Islam, toleransi dalam pengertian kelompok ekstrimis akan berbeda dengan pengertian toleransi yang diartikan oleh kelompok moderat atau kelompok lain yang lebih mementingkan perdamaian namun mereka tetap berpendapat bahwa konsep toleransi dalam pengertian mereka yang benar.

Untuk membatasi pengertian toleransi yang terlalu variatif dan sebagai alat analisis untuk membahas tema yang akan dielaborasi lebih lanjut maka toleransi di sini diartikan sebagai suatu sikap atau perilaku manusia yang tidak menyimpang dari aturan agama, di mana seseorang saling menghargai, menghormati, dan memberikan ruang gerak yang begitu luas bagi pemeluk agama untuk memeluk agamanya masing-masing tanpa adanya unsur paksaan dari pemeluk agama lain. Dengan demikian, masing-masing pemeluk agama dapat menjalankan ritual agamanya dengan rasa kedamaian (Mursyid, 2018).

Menurut Quraish Shihab bahwa semakin tinggi pengetahuan seseorang bisa diharapkan semakin tinggi toleransinya. Sebaliknya, semakin rendah pengetahuan seseorang dan latar belakang pendidikannya, semakin besar kemungkinan timbulnya hal-hal negatif (Shihab, 2012). Amien Rais mengafirmasi dengan bahasa yang berbeda bahwa Islam menoleransi perbedaan pendapat di kalangan umatnya walaupun perbedaan cukup tajam selama perbedaan muncul oleh kemauan untuk mencari kebenaran dan masing-masing pihak tidak boleh memonopoli kebenaran (Rais, 2012).

Terkait batasan toleransi terhadap antar pemeluk agama maka sepanjang bukan merupakan ranah Aqidah maka toleransi diperbolehkan, bahkan cenderung sebagai sebuah keharusan bagi setiap umat beragama untuk menjunjung tinggi kehidupan toleran demi tujuan 
mencapai kehidupan bersama yang damai dan manusiawi. Toleransi seperti ini yang kemudian menjadi spirit bagi Imam Shamsi Ali dalam proses rekonstruksi citra Islam dan Indonesia di bumi Amerika Serikat. Konsepsi toleransi yang sudah langka dalam kehidupan beragama. Fenomena terorisme yang menjangkiti sebagian kecil umat Islam disebabkan karena pemahaman tentang konsep Khairu Ummah yang kebablasan dan sikap toleransi mereka yang sangat sempit.

Toleransi menjadi konsep yang sangat krusial di masa sekarang ketika umat antar agama hidup dalam iklim yang saling mencurigai satu sama lain. Toleransi adalah jalan tengan untuk mendamaikan dan menemukan titik temu yang selama ini diselesaikan melalui konfrontasi, dengan jalan toleransi, semua pihak yang berbeda duduk bersama dalam mencari solusi dan rekonsiliasi dengan tujuan untuk kebaikan bersama.

\section{Hasil dan Pembahasan}

Pembahasan selanjutnya akan mengelaborasi sejauh mana fenomena Islamophobia yang lazim di tengah masyarakat Amerika Serikat dan memandang Islam sebagai sebuah entitas yang patut untuk dicurigai sebagai musuh. Kemudian fenomena tersebut akan dikaitkan dengan usaha Imam Shamsi Ali dalam mempromosikan Islam sebagai sebuah nilai yang berbeda dari apa yang distigmatisasi oleh masyarakat Amerika Serikat pada umumnya. Imam Shamsi Ali mengedepankan toleransi dalam batas-batas yang wajar untuk memperlihatkan wajah Islam yang sebenarnya.

Berikut berbagai penghargaan yang diperoleh oleh Imam Shamsi Ali sebagai salah satu indikator keberhasilan dalam menjalankan dakwah melalui dialog interfaith di Amerika Serikat.

Tabel 1. Keberhasilan Imam Shamsi

\begin{aligned} & \hline Tahun \multicolumn{1}{c}{ Keterangan } \\ & \hline 2001 $\begin{array}{l}\text { Mewakili Komunitas Muslim dalam pertemuan Pimpinan agama se-New York merespon serangan teroris } \\ \text { tersebut }\end{array} \\ &$\hline 2001 Mewakili Komunitas Muslim dalam acara Nasional "Prayer for Amerika" di Yankee Stadium New York \\ & \hline 2001 $\begin{array}{l}\text { Menjadi salah satu dari dua Imam yang diundang untuk menemani Presiden George W. Bush di saat } \\ \text { mengunjungi Ground Zero }\end{array} \\ &$\hline 2002 Diangkat menjadi "Liaison" (penghubung) antara Komunitas Islam dan Kepolisian New York (NYPD) \\ & \hline 2006 $\begin{array}{l}\text { Dinobatkan sebagai salah satu dari tujuh tokoh agama yang paling berpengaruh di New York City oleh New York } \\ \text { Magazine }\end{array} \\ &$\hline 2006 Berpartisipasi dalam konferensi internasional Imam dan Rabi untuk perdamaian di Sevilla, Spanyol \\ & \hline 2007 $\begin{array}{l}\text { Mewakiliki Komunitas Muslim pada diskusi antar agama dalam acara dialog agama dan pembangunan } \\ \text { berkelanjutan di Gedung Putih }\end{array} \\ &$\hline 2007 Berpartisipasi dalam National Summit pertama Imam dan Rabi Amerika Utara \\ & \hline 2008 Menjadi keynote speaker di Jewish-Muslim for Peace di Sevilla, Spanyol \\ & \hline 2008 Berpartisipasi dalam dialog antar Agama Transalantic di frankfurt, Jerman \\ & \hline $2009-2014 \begin{array}{l}\text { Terpilih sebagai salah satu dari 500 Muslim paling berpengaruh di dunia oleh studi Islam Royal Center Strategis } \\ \text { di Yordania dan Universitas Georgetown }\end{array} \\ &$\hline $2010-2015$ Diangkat menjadi instruktur dalam "Cultural Sensitivity Training" di Kepolisian New York \\ & \hline Sumber: Nusantarafoundation (2021) Peningkatan kekerasan terhadap umat Muslim di Amerika Serikat mengalami \\ & Peningkatan yang cukup signifikan pasca tragedi 9/11. \end{aligned}




\section{Jumlah Insiden Kekerasan Terhadap Umat Muslim Pasca 9/11}

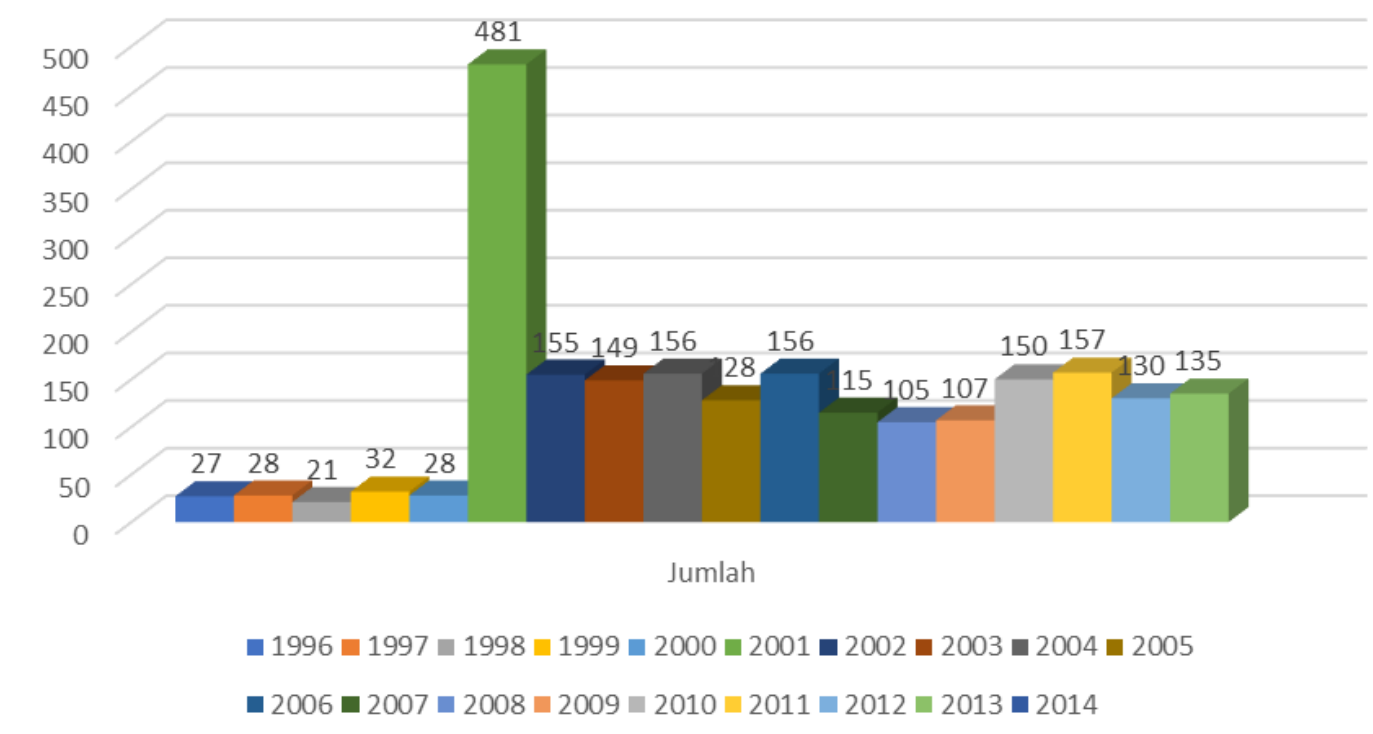

Sumber: (Ser, 2016)

Gambar 1. Jumlah Insiden Kekerasan Terhadap Umat Muslim Pasca 9/11

\subsection{Perkembangan Islamophobia dan Stigma Negatif Terhadap Indonesia Di Amerika} Serikat

Pertanyaan yang muncul pertama kali ketika membahas kehidupan Islam dan Indonesia di tengah masyarakat Amerika Serikat adalah apa penyebab munculnya stigma negatif terhadap Islam dan Indonesia di Amerika Serikat. Untuk menjawab terkait keindonesiaan, mungkin sedikit lebih mudah karena sejarah keterkaitan Indonesia sebagai sebuah negara bangsa dengan Amerika Serikat, baru berlangsung sekitar 75 tahun sejak Indonesia merdeka. Stigma negatif Amerika Serikat terhadap Indonesia bisa ditarik garis lurus dari peristiwa serangan 9/11 dan rentetan bom bunuh diri yang terjadi di Indonesia pasca serangan 9/11 yang mayoritas dilakukan oleh kelompok yang mengatasnamakan pembela Islam.

Selain itu, Indonesia juga adalah negara dengan populasi Muslim terbanyak di dunia sehingga Indonesia diidentikkan dengan Islam dengan segala atribut yang dengan sengaja dikonstruksi oleh media barat. sebuah stigmatisasi yang bias karena sebagian masyarakat Amerika Serikat secara umum bahkan belum mengetahui secara pasti corak Islam seperti apa yang berkembang di Indonesia. Media dalam hal ini memberi sumbangsih yang paling signifikan dalam membentuk citra yang negatif. Simplifikasi identitas Islam yang dilakukan oleh negara barat menjadikan Islam dipandang sebagai sebuah identitas tunggal. Hal ini menjadikan citra Islam di Indonesia dianggap sama dengan karakter mayoritas penduduk Muslim di Timur Tengah sering dilanda konflik.

Pembahasan terkait stigma negatif Amerika Serikat terhadap Islam secara umum atau yang lebih populer dikenal dengan istilah Islamophobia, mempunyai sejarah yang lebih panjang, maka tidak serta merta dipetakan pasca serangan 9/11. Tidak bisa dipungkiri bahwa 
pasca peristiwa tersebut, Islamophobia di Amerika Serikat meningkat drastis namun tidak bisa disimpulkan secara langsung bahwa kejadian itu menjadi prima cause lahirnya Islamophobia di Amerika Serikat, sebaliknya harus dirunut ke belakang sebelum peristiwa 9/11. Meskipun menjadi populer di tahun 2001, sebenarnya Islamophobia dalam hal pemaknaan sudah ada sejak zaman Rasulullah Saw karena terdapat golongan yang phobia terhadap Islam sedangkan dalam konteks dunia barat, Islamophobia dipublikasikan oleh Runnymede Trust dalam sebuah laporan "Islamophobia: Challenge for Us all" pada tahun 1997. Sedangkan menurut Christopher Allen bahwa Islamophobia secara konsep maupun neologisme pertama kali berasal dari Inggris (Allen, 2010).

Merunut ke belakang sebelum konsepsi Islamophobia muncul, sejarah perang Salib (1096-1291) tidak bisa dinafikan sebagai sebuah momentum meningkatnya stigma negatif terhadap Islam di abad Modern. Perang Salib bisa dikategorikan sebagai momen paling awal terbentuknya stigma negatif orang barat termasuk masyarakat Amerika Serikat terhadap dunia Islam. Ada semacam dendam yang belum termanifestasikan terhadap Islam yang pernah menguasai wilayah Eropa. Citra Barat terhadap Islam tentu saja memiliki pijakan historisnya tersendiri, bahkan telah dimulai sejak berkobarnya Perang Salib pada abad ke-11 dan ke-12, dimana telah mengobarkan semangat fanatisme keagamaan yang diarahkan secara langsung untuk berperang melawan kaum Saracen (Alim, 2020). Rasa kebencian bangsa barat terhadap Islam diekspresikan selain dalam bentuk kekerasan fisik juga dalam bentuk verbal seperti julukan yang merendahkan dengan sebutan kaum Saracen.

Stigma negatif Amerika Serikat terhadap Islam seperti menjadi pemantik bagi golongan Islam radikalisme untuk menjadikan hal tersebut sebagai alasan melawan Amerika Serikat, alihalih menempuh jalan dialog untuk memperbaiki citra Islam yang damai. Hal ini yang kemudian memperkeruh keadaan karena sangat jarang diantara kedua kelompok (Islam dan bangsa Barat) berusaha untuk merefleksikan diri untuk mencari cara lain dalam mendamaikan situasi, satu dari sedikit tokoh Islam di Amerika Serikat yang melawan arus menempuh jalan dialog dalam mencari titik masalah dalam ketegangan ini adalah Imam Shamsi Ali yang berasal dari Indonesia. Keputusan untuk berdialog lintas agama menjadi cara paling efektif dalam meredakan ketegangan bahkan dengan kaum Yahudi sekalipun.

Imam Shamsi Ali berada di Amerika Serikat tepatnya di New York pada tahun 1996, enam tahun sebelum terjadinya peristiwa $9 / 11$, pada saat meningkatnya citra buruk terhadap Islam secara umum dan Indonesia secara khusus sebagai representasi negara dengan populasi Muslim terbesar. Melihat kondisi yang ada, Imam Shamsi Ali memilih jalannya sendiri untuk memperbaiki citra Islam dan Indonesia alih-alih mendukung tindakan teroris yang dilakukan Stigma negatif Amerika Serikat terhadap Islam seperti menjadi pemantik bagi golongan Islam radikalisme untuk menjadikan hal tersebut sebagai alasan melawan Amerika Serikat, alih-alih menempuh jalan dialog untuk memperbaiki citra Islam yang damai. Hal ini yang kemudian memperkeruh keadaan karena sangat jarang diantara kedua kelompok (Islam dan bangsa Barat) berusaha untuk merefleksikan diri untuk mencari cara lain dalam mendamaikan 
situasi, satu dari sedikit tokoh Islam di Amerika Serikat yang melawan arus menempuh jalan dialog dalam mencari titik masalah dalam ketegangan ini adalah Imam Shamsi Ali yang berasal dari Indonesia. Keputusan untuk berdialog lintas agama menjadi cara paling efektif dalam meredakan ketegangan bahkan dengan kaum Yahudi sekalipun.

Imam Shamsi Ali berada di Amerika Serikat tepatnya di New York pada tahun 1996, enam tahun sebelum terjadinya peristiwa 9/11, pada saat meningkatnya citra buruk terhadap Islam secara umum dan Indonesia secara khusus sebagai representasi negara dengan populasi Muslim terbesar. Melihat kondisi yang ada, Imam Shamsi Ali memilih jalannya sendiri untuk memperbaiki citra Islam dan Indonesia alih-alih mendukung tindakan teroris yang dilakukan sebagian kecil kelompok Islam. Sebagai seorang Muslim yang tumbuh di lingkungan Islam yang sangat homogen sejak kecil di Indonesia, kemudian kuliah di Pakistan dan pindah Arab Saudi, membuat prasangka terhadap non- Muslim khususnya terhadap Yahudi, sangat kuat di kepalanya. Stigma bahwa non-Muslim selalu mempunyai tendensi menghancurkan Islam, selalu membayangi pikirannya meskipun secara sadar menyadari bahwa konstitusi Amerika Serikat melindungi semua golongan yang hidup di negara tersebut. Persahabatan Imam Shamsi Ali dengan Rabi Marc Schneier pun dimulai dari saling curiga antara keduanya. Rabi Marc Schneier adalah seorang pemeluk yahudi yang taat. Schneier lebih sering menghabiskan masa kecilnya di Sinagoge daripada di rumah. Tidak mengherankan jika sebelum bertemu dan bersahabat dengan Imam Shamsi Ali, pandangannya terhadap Islam dikonstruksi oleh media dan informasi sekunder yang sudah bias.

Stigma negatif Imam Shamsi Ali terhadap pemeluk agama lain, ditepis dengan cara melakukan dialog Interfaith yang akhirnya membawa Imam Shamsi Ali dalam mengambil sebuah kesimpulan bahwa semua pemeluk agama pada dasarnya adalah manusia yang memiliki sisi kemanusiaan yang ingin berdamai. Imam Shamsi Ali menjadi representasi ajaran Islam "Khairu Ummah" dalam pengertian yang sesungguhnya. Umat yang paling bermanfaat dan suka menolong orang lain, yang berusaha menyuruh pada kebaikan, mencegah keburukan dan yakin pada keesaan Tuhan (Schneier \& Ali, 2014).

\subsection{Signifikansi Pengaruh Imam Shamsi Ali dalam Merekonstruksi Citra Islam dan Indonesia di Mata Masyarakat Amerika Serikat}

Proses dialog antar umat beragama (interfaith dialogue) yang ditempuh oleh Imam Shamsi Ali dalam hal rekonstruksi citra Islam dan Indonesia di Amerika Serikat, tidak jarang mendapat kontra dari kelompok Islam sendiri yang bahkan menganggap Imam Shamsi Ali tidak sepantasnya menempuh jalan dialog antar agama khususnya dengan kaum Yahudi, namun pendirian Imam Shamsi Ali tidak goyah, dengan konsep Toleransi yang dipahami bahwa bergaul antar pemeluk agama sama sekali tidak dilarang oleh agama sepanjang dalam batasan tertentu dan tetap menjaga perdamaian dan hubungan baik dengan sesama manusia, bahkan sebaliknya, konsep Khairu Ummah seharusnya diartikan sebagai sebuah konsep yang membawa damai kepada semua umat manusia tanpa pengecualian. 
Selama 25 tahun hidup di New York dalam rangka menebarkan nilai-nilai Islam melalui dialog interfaith, Imam Shamsi Ali menemui berbagai hambatan. Salah satu hambatan yang cukup signifikan adalah pemahaman bahwa Islam seringkali diidentikkan dengan corak yang melekat pada masyarakat Timur Tengah termasuk budaya yang keras, sedangkan Imam Shamsi Ali yang berasal dari Indonesia, mempunyai corak Islam yang khas dan berbeda dengan corak keislaman Timur Tengah secara budaya. Masyarakat Indonesia yang heterogen dan mengedepankan musyawarah mufakat dalam setiap pengambilan keputusan, menjadi modal dasar bagi Imam Shamsi Ali dalam menyebarkan pesan-pesan Islam yang damai di Amerika Serikat.

Jalan dialog yang ditempuh oleh Imam Shamsi Ali dalam memperkenalkan Islam dan Indonesia yang damai tidak terlepas dari sejarah masa lalu. Imam Shamsi Ali memang tumbuh di desa yang sangat homogen dalam hal beragama namun kehidupan beragama di kampungnya tidak disertai dengan sikap fanatik buta terhadap identitas agama. Pengalaman lain yaitu realitas di Arab Saudi yang dialaminya atas diskriminasi yang sangat kuat terhadap golongan non-Arab khususnya TKW dari Indonesia. Imam Shamsi Ali sering menemukan tulisan di lipatan kertas di sepanjang jalan depan apartemen yang tertulis "tolong saya pak, Pak...tolong selamatkan Saya." (Nava, 2013). sebuah kenyataan yang terdampar di depan mata yang merefleksikan bahwa diskriminasi dan kekejaman adalah sebuah realitas yang nyata dan selalu meninggalkan luka kemanusiaan. Sebuah kenyataan hidup yang memberi andil dalam paradigma Imam Shamsi Ali bahwa persoalan kemanusiaan tidak berhenti ketika seorang menjadi pemeluk Islam.

Pada satu kesempatan bedah buku di Universita Islam Indonesia, Imam Shamsi Ali memaparkan satu peristiwa di awal perjalanan dakwahnya di Amerika Serikat, Imam Shamsi Ali pernah diundang ceramah di sebuah sekolah dan membaca buku yang diajarkan kepada siswa. Di sana siswa diajarkan semua agama namun Islam disimbolkan sebagai agama dalam buku tersebut sebagai sosok yang berjubah dan bertubuh besar sambil memegang pedang dan berdiri di tengah gurun pasir. Sebuah gambaran Islamophobia yang tumbuh subur di Amerika Serikat yang membuatnya berpikir bahwa harus ada usaha untuk mengeliminir fenomena yang menyudutkan Islam, dan jalan tersebut bukan sebuah jalan kekerasan fisik karena akan menambah pelik permasalahan. Jalan yang ditempuh harus berupa dialog untuk menemukan solusi dan merendahkan diri di depan kelompok lain.

Identitas yang ditampilkan oleh Imam Shamsi Ali selama menempuh jalan dakwah di Amerika Serikat bukan sebuah identitas yang sifatnya fisik seperti memelihara janggut, menghitamkan jidat, atau bahkan menggunakan celana yang menghindari Isbal, namun identitas keislaman yang diperkenalkan termanifestasi dalam tindakan yang membawa kedamaian bagi orang lain. Di awal-awal dakwah, Imam Shamsi Ali sering mendapat kritikan dari sebagian umat Muslim karena tidak mengenakan jubah dan tidak memelihara jenggot. Imam Shamsi Ali berpendapat bahwa jubah adalah budaya dalam hal pakaian dan bahwa kita 
sebagai Muslim khususnya dari Indonesia mempunyai Identitas tersendiri yang berhubungan dengan pakaian yang tetap sesuai dengan nilai Islam.

Dalam Islam, terdapat konsep Khairu Ummah. "Kamu adalah umat yang terbaik yang dilahirkan untuk manusia" (QS Ai Imran (3); 110). Imam Shamsi Ali memaknasi Khairu Ummah bukan dalam pemaknaan yang sempit dan fanatik bahwa umat Islam adalah umat terbaik yang sudah given dari Tuhan namun Imam Shamsi Ali berpandangan bahwa Khairu Ummah adalah umat yang bermanfaat dan suka menolong orang lain, berusaha menyeruh pada kebaikan, mencegah keburukan dan yakin pada keesaan dan keagungan Tuhan (Schneier \& Ali, 2014). Konsepsi ini menurut Imam Shamsi Ali tidak terbatas pada umat Muslim namun juga nonMuslim yang berjuang demi kemanusiaan. Hal ini dimanifestasikan Imam Shamsi Ali dalam wujud dakwah seperti ceramah di berbagai Gereja, Sinagog atas nama kemanusiaan. Dalam agama Yahudi, dikenal konsep "Bangsa yang terpilih." Imam Shamsi Ali mengkompromikan kedua konsep tersebut sebagai sebuah hal yang harus diusahakan, bukan konsepsi yang given dari Tuhan.

Implikasi dari perjalanan dakwah yang toleran dan Inklusif sering digambarkan dalam kejadian-kejadian kecil yang terjadi dalam perjalanan kehidupannya. Seperti ketika Presiden Amerika Donald Trump mengeluarkan kebijakan tentang melarang muslim masuk di Amerika, seorang pemimpin Yahudi mendatangi dirinya dan bertanya. "Apa yang bisa saya bantu. Di lain waktu, Imam Shamsi Ali berkisah ketika seorang perempuan mendatangi dirinya dan memaki dan mengolok-olok nabi Muhammad Saw. Imam Shamsi Ali mengatakan sangat marah namun ia membayangkan bagaimana bila seandainya Nabi berada pada posisi tersebut. "Maka ketika dia selesai bicara dan hendak pulang saya memanggilnya, mendatangi dan mengajaknya salaman sambil tersenyum," kata Imam Shamsi Ali. beberapa pekan setelahnya, perempuan itu datang lagi dan mengatakan "saya tidak bisa tidur nyenyak semenjak hari itu". Dia mengaku heran dan merasa ada yang salah terhadap cara pandangnya terhadap Islam. "Sejak saat itu dia tertarik belajar Islam, saat ini dia selalu menerjemahkan Alquran dan membagikan kepada masyarakat yang lewat," paparnya (Kamsah, 2019).

Sebuah konsep dakwah yang toleran dalam batasan lazim, dakwah yang inklusif, ramah terhadap semua dan bentuk dakwah yang menempuh jalan damai, dijalani oleh Imam Shamsi Ali di tengah pro dan kontra dari umat Islam sendiri namun tidak mengurangi usahanya untuk memperkenalkan Islam yang rahmatan lil alamin. Jalan dakwah yang pada akhirnya mengantarkan Imam Shamsi Ali dalam posisi yang dihormati oleh penganut agama lain.

Secara kualitatif, keberhasilan Imam Shamsi Ali dalam merekonstruksi citra Islam dan Indonesia di tengah masyarakat Amerika Serikat memang tidak bisa diinventarisir secara terukur karena sifatnya sangat subjektif, namun jika ingin mengkuantifikasi maka bisa diukur dari penghargaan yang berhubungan dengan kehidupan toleransi antar agama yang diterima dari Pemerintah setempat antara lain Penghargaan dalam bidang hubungan antara agama dari City Council New York, diangkat sebagai "Duta Perdamaian" oleh Federasi Agama penghargaan Interfaith ICLI 2008, dinobatkan sebagai satu dari tujuh tokoh agama paling 
berpengaruh di New York City oleh New York Magazine tahun 2006. (Nusantara Foundation, 2021) dan beberapa penghargaan lain yang menjadi ukuran kuantitatif bahwa eksistensi Imam Shamsi Ali di Amerika Serikat khususnya di New York sangat diperhitungkan dalam kehidupan lintas agama dengan tetap membawa Identitas Islam dan Indonesia dalam setiap interaksinya. Salah satu penghargaan yang sangat prestise adalah Ellis Island Honor Award yang diterimanya tahun 2009, penghargaan itu menjadi sangat spesial karena baru dua orang Muslim yang menerimanya. Tokoh Muslim lain yang juga dianugerahi penghargaan yang sama adalah Muhammad Ali, petinju termasyur yang diidolakan hampir seluruh masyarakat Amerika Serikat bahkan seluruh dunia baik yang beragama Islam maupun non-Islam. Sebuah penghargaan yang didedikasikan kepada imigran atau keturunan imigran yang berjasa terhadap Amerika Serikat. Imam Shamsi Ali juga dimasukkan dalam daftar 50 orang berpengaruh di Queens, New York City karena dianggap sebagai aktivis perdamaian ("Queens Power 50," 2020).

Perjuangan Imam Shamsi Ali semakin berat tantangannya pasca terpilihnya Donald Trump sebagai Presiden Amerika Serikat tahun 2016. Sentimen terhadap umat Muslim di era Donald Trump kembali meningkat meskipun tidak sebesar seperti pada saat tragedi 9/11. Hal tersebut dipicu oleh kebijakan-kebijakan Trump yang tidak pro terhadap kelompok Imigran secara umum dan umat Muslim secara khusus. Donald Trump membuat kebijakan dengan melarang warga dari Suriah, Irak, Sudan, Libya dan Somalia masuk ke Amerika Serikat karena menganggap bahwa negara-negara tersebut identik dengan Radikalisme. Sebuah kebijakan yang mendapat protes luas dari berbagai kalangan meskipun kebijakan tersebut dibatalkan Mahkamah Agung namun tidak bisa dipungkiri bahwa kebijakan semacam itu kembali melahirkan citra negatif terhadap Islam di Amerika Serikat seiring pula dengan meningkatnya "White Supremacist." Imam Shamsi Ali selalu meneriakkan penentangan terhadap setiap kebijakan yang rasialis bukan atas nama Islam secara khusus namun atas nama golongan masyarakat yang tertindas seperti sejak awal Donald Trump terpilih sebagai presiden Amerika Serikat, Imam Shamsi Ali sering berseberangan dengan kebijakan imigrasi Presiden Donald Trump yang diskriminatif.

Pemilihan presiden Amerika Serikat tahun 2020 dimenangkan oleh Joe Biden mengalahkan incumbent, Donald Trump yang terkenal dengan pola kepemimpinan yang otoriter, namun bukan berarti bahwa dengan begitu rasialisme di Amerika Serikat akan hilang begitu saja. Persoalan rasialis yang dialami oleh umat Islam di Amerika Serikat yang termanifestasikan dalam isu Islamophobia, menjadi persoalan yang krusial. Seperti yang dinyatakan oleh Rektor UKI, A Prasetyantoko bahwa kekalahan Trump tak serta merta membuatnya melenggang dari Gedung putih begitu saja. Sejatinya, Biden tak sekadar berkompetisi melawan petahana Trump di ajang pilpres, lebih jauh lagi, dia bertarung dengan sebuah pandangan politik yang sejak 2016 telah mendapat dukungan luas, kalaupun Trump pergi dari Gedung putih, tak begitu dengan Trumpisme (A Prasetyantoko, 2020). Trumpisme di sini mencakup banyak hal termasuk garis politik Donald Trump yang rasialis. 
Pergantian presiden Amerika Serikat yang sekarang dijabat oleh Joe Biden, mempunyai implikasi yang sedikit meringankan beban Imam Shamsi Ali karena beberapa kebijakan di awal pemerintahan Joe Biden yang lebih permisif terhadap Islam. Terbukti Joe Biden sudah mencabut kebijakan Donald Trump tentang aturan mengenai pembatasan masuknya warga dari negara yang penduduknya mayoritas beragama Islam seperti dari negara Yaman, Somalia, Irak, Iran, Suriah, Libya, dan Sudan (Intan, 2021). Kebijakan tersebut tentunya menjadi angin segar bagi Imam Shamsi Ali dalam mempromosikan Islam. meskipun demikian, kondisi eksternal tidak berpengaruh signifikan karena Imam Shamsi Ali akan tetap berjalan pada koridornya dalam membawa nilai Islam di Amerika Serikat dalam keadaan apapun. kunci dari dakwah Imam Shamsi Ali adalah membawa nilai Islam dalam suasana penuh toleransi sehingga bagaimana pun kondisinya, masyarakat akan menerima Islam sebagai sebuah agama yang damai.

\section{Kesimpulan}

Imam Shamsi Ali mampu merekonstruksi citra Islam dan Indonesia di Amerika Serikat dengan cara menerapkan konsep Toleransi dalam berinteraksi dengan lintas agama bahkan dengan kaum Yahudi yang selama ini dipersepsikan sebagai musuh Islam. Sesuatu yang selama ini dianggap tabu karena persepsi sebagian orang Islam bahwa orang Yahudi senantiasa ingin menghancurkan Islam dalam berbagai hal. Stigma tersebut tidak lepas dari konflik Palestina-Israel yang berkepanjangan. Metode dakwah Imam Shamsi Ali yang inklusif, toleran, ramah, damai dan penuh persahabatan menjadikannya sebagai pribadi yang diterima di semua kalangan di Amerika Serikat sekaligus berimplikasi baik terhadap citra Islam dan Indonesia. Keberhasilan dakwah yang memanusiakan penganut agama lain karena sejatinya bahwa apapun agama seseorang, pada intinya mereka adalah seorang manusia yang jika sisi kemanusiaannya disentuh, maka pertentangan mengenai identitas-identitas selain kemanusiaan itu sendiri akan tereliminasi dan tercipta kedamaian antara sesama manusia tanpa pertimbangan identitas keagamaan, ataupun identitas lainnya yang bersifat artifisial. Sebuah jalan dakwah yang mulai jarang ditemukan di tengah umat Islam. Metode dakwah inklusif yang direpresentasikan oleh Imam Shamsi Ali akan membawa sebuah rekonsiliasi antara Islam dan dunia Barat yang selama ini hidup dalam saling kecurigaan. Persahabatan Imam Shamsi Ali dengan Rabi Marc Schneier yang pada awalnya saling menaruh kecurigaan, bisa menjadi gambaran nyata bagaimana jalan yang harus diretas Islam dan dunia barat bahwa jalan tengahnya adalah berdialog untuk menemukan titik terang.

\section{Daftar Pustaka}

A Prasetyantoko. (2020). Menanti Gebrakan "Bidenomics". Kompas.ld. https://www.kompas.id/baca/opini/2020/11/10/menanti-gebrakan-bidenomics/

Alim, S. (2020). Dinamika Historis Barat-Islam: Mispersepsi, Prasangka, dan Konflik. Mimbar Agama Budaya, 33-44. 
Allen, C. (2010). Islamophobia. Ashgate Publishing.

Bakry, U. . (2016). Metode Penelitian Hubungan Internasional. Pustaka Belajar.

Dixon, T. (2011). The Question of Identity: The EU/Turkey Integration Debate. 1-9. http://www.e-ir.info/2011/07/21/the-question-of-identity-the-euturkey-integration-debate/

Fukuyama, F. (2018). Identity: The demand for dignity and the politics of resentment. Farrar, Straus and Giroux.

Intan, P. (2021). Joe Biden Penuhi Janji, Cabut Larangan Masuk dari Beberapa Negara Muslim. Detik.Com.

Kamsah. (2019). Muhammad Shamsi Ali Cerita Soal Perjuangannya Sebarkan Islam di Amerika. Makassar.Terkini.Id. https://makassar.terkini.id/muhammad-shamsi-ali-ceritasoal-perjuangannya-sebarkan-islam-di-amerika/

Love, E. (2017). Islamophobia and racism in America. NYU Press.

Mas'oed, M. (1994). IImu hubungan international: disiplin dan metodologi. PT Pustaka LP3ES.

Mursyid, S. (2018). Konsep Toleransi (Al-Samahah) Antar Umat Beragama Perspektif Islam. Aqlam: Journal of Islam and Plurality, 1(2).

Nava, J. (2013). Imam Shamsi Ali, Menebar Damai Di Bumi Barat (1st ed.). Noura Book.

Nusantara Foundation. (2021). Penghargaan Imam Shamsi Ali. Nusantarafoundation.Org. https://nusantarafoundation.org/imam-shamsi-ali/penghargaan/

Queens Power 50. (2020). City and State New York.

Rais, A. (2012). Semangat Berkorban, Sendi Persaudaraan. Mizan.

Schneier, R. M., \& Ali, I. S. (2014). Anak-Anak Ibrahim, Dialog Terbuka Mengenai Isu-Isu yang Memisahkan dan Menyatukan Muslim-Yahudi (1st ed.). Noura Books.

Ser, K. K. K. (2016). Data: Hate crimes against Muslims increased after 9/11. Pri.Org.

Shihab, Q. (2012). Mengikis Fanatisme dan Mengembangkan Toleransi. Mizan.

Wendt, A. (1992). Anarchy is what states make of it: the social construction of power politics. International Organization, 46(2), 391-425.

Wendt, A. (1994). Collective identity formation and the international state. American Political Science Review, 384-396. 